\title{
On the Environmental Responsibility of Coal Enterprises in Mongolia
}

\author{
PUREVSUREN AZZAYA ${ }^{1,}$ a, Xinkai $\mathrm{Hu}^{2, \mathrm{~b}}$ and Sichang Wang ${ }^{3, \mathrm{c}}$ \\ ${ }^{1}$ Shanghai University, No. 99, Shangda road, Baoshan District, Shanghai, China \\ 2Shanghai University, No. 99, Shangda road, Baoshan District, Shanghai, China \\ ${ }^{3}$ Shanghai University, No. 99, Shangda road, Baoshan District, Shanghai, China \\ a1878229348@qq.com, b640217281@qq.com, csharecake@126.com
}

\begin{abstract}
Key words: environmental responsibility; Mongolia; coal enterprises; corporate social responsibility Abstract. The coal industry has always been an important supporting and safeguarding industry for Mongolia's economic development. Driven by the global economic integration, the economic benefit of coal enterprises has greatly improved, and Mongolia's domestic economy, the coal industry, coal enterprises are ushered in new development opportunities. While the Mongolia's economy and the coal enterprises develop quickly, the contradiction between environmental protection and enterprise growth becomes increasingly prominent. We aim at the non-institutional and supervision inadequate problems the current Mongolia coal enterprises encountered in the process of expanding the scale in this paper. From the perspective of corporate environmental responsibility, we carefully study the responsibility segments of Mongolia coal enterprises in rapid development. Based on the successful experiences from other coal companies, we stimulate Mongolia coal enterprises with these countermeasures: promoting economic development with legal constraints, having a proper integration of exploitation, protection and development, and developing the circular economy.
\end{abstract}

\section{Introduction}

Mongolia is one of the few countries with abundant coal resources in the world, and can rapidly develop the market of mineral resources, such as coal, when prices going all the way down. Established in 1921, after the development in the Soviet period, Mongolia began in exploration and exploitation on coal and other mineral resources. After many years of development, especially since the 1989 reform, Mongolia has identified a new mode of economic development, to push the exploration of various mineral resources to further extent. According to incomplete statistics, the current reserves of coal resources in Mongolia is quite rich, which is about 162.3 billion tons, mainly concentrated in northern Mongolia, central and southern Gobi provinces, 200 meters to 400 meters beneath the earth's surface. In the past, due to technical restrictions, coal mainly applied in power generation and residential heating. With the continuous development and progress of modern technology, a series of new technologies, such as coal gasification, coking, liquefaction and other technologies came out and became quite mature, so Mongolia began to export a large number of domestic high-quality coal resources to foreign countries, which is currently the main way to promote the growth and upgrade of Mongolia's economy. According to the statistics of relevant departments of Mongolia, there are about 300 large coalmines in the 15 coal-enriched basins in Mongolia, with proven reserves of 20 billion tons of coal resources, which make Mongolia one of world's top 10 coal reserves countries. In particular, Mongolia is now aiming at the rapid economic recovery and development in Asia, ready to better grasp and take advantage of this opportunity, expand the scale of their mining industry by selling coal and other mineral resources to other Asian countries, and ultimately further promote the domestic economy development. 
At present, while Mongolian coal enterprises are in process of expanding their production scale, rapidly increasing economic efficiency, the environmental issues are becoming more and more prominent. As we have learned lessons from western countries' dilemma of dealing with the conflicts between environmental protection and resource development, Mongolia's economic development can no longer continue to step into the old way of "growing first, cleaning up later". Therefore, how to analyze the direction and the way of the future development of the coal enterprises in Mongolia, how to learn development mode and experiences from foreign enterprises to further research, explore and solve the conflicts between economy development and environment protection, are becoming particularly important.

\section{Coal Enterprises Environmental Responsibility}

Concept of coal enterprises CER. Environment is the basis of our survival, especially at present, the concept of harmonious development of human and ecological environment began to be widely accepted and publicized. Economic development mode has also shifted from the past extensive form to circular economy, which is not only an important way to maintain the current economic development and ecological balance, but also a significant mode for enterprises to undertake their responsibilities for environment protections.

Enterprise, as an important economic carrier in today's society, has done great contribution to economic growth, but it also can be devastating to natural environment. Therefore, we urge them to strive to adjust and improve their own economic development mode, to assume responsibility for the protection of the ecological environment in their pursuit of profit, unconditionally. Wu Limin (2001) put forward in his discussion on environmental responsibility and social responsibility of enterprises that "Corporate Social Responsibility (CSR) is a relatively broad concept, in which Corporate Environmental Responsibility (CER) is the main manifestation of CSR under the mode of circular economy. In the process of "reduction, recycle resources for re-utilization", for enterprises, the main social responsibility is being responsible for the ecological environment and natural resources by protection and scientific use. CER refers to the protection for the natural environment involved in its construction and production progress. Bai Pingze (2006) argued that dualistic economic goal (profit maximization and environmental responsibility) is unrealistic to the development of the enterprise. CER is to seek to protect the environment while pursuing maximum economic benefit and interests for shareholders. Wu Jiaojun (2007) stressed that environmental legal responsibility is the most direct and effective of the forms. Therefore, CER must be undertaken in the production and business activities. This kind of responsibility would adhere to the whole business activities of the company, and would not stop with the disappearance of enterprises.

Foreign scholars and various social organizations also have different views and perspectives on CER. American scholar Carol put forward the concept of enterprise "greening". He believes that the "greening" carried out by enterprises should be a more popularized activity, a social activity without boundaries, which belongs to an environmentalism society. Meanwhile, the environmental problems of enterprises will also exist for a long time. Pollution Probe specifically emphasized what CER is in the relevant report. The report states that the environmental responsibility of the enterprise: "Corporate environmental responsibility makes economy sustainably developed, while not adversely affect the environment and society. It can meet the ecological requirements of the raw materials and energy management system, enable the corporate environmental information transparency by effective stakeholder participation. Georges Enderle (2008) pointed out that the concept of sustainable development is the guide of CER. According to Graff Zivin (2005), CER is mainly committed to sustainable development to consume fewer natural resources, drop less waste. 


\section{Weakness of coal enterprises' CER in Mongolia}

Non-institutional. "CER means the enterprise should use science and technology for scientific production and management, in order to fulfill the protection of the ecological environment, conservation of natural resources, common interests of the public when seeking maximum economic benefits. Corporate environmental responsibility consists of corporate environmental moral responsibility and corporate environmental legal responsibility." Similarly, the responsibility of environmental protection of coal enterprises also involves the two aspects. The environmental moral responsibility belongs to the ethical category, which emphasizes that the coal enterprises should take their social responsibilities and missions when they engage in relevant social and economic activities, and this need to be maintained by the whole society through raising self-awareness and consciousness, while environmental legal responsibility should make the full use of the restraint and punishment to compensate for the lack of environmental moral responsibility. Currently, the institutional management has not yet fully implemented, and corporate environmental responsibility remains at the superficial level.

Supervision inadequacy. At present, we talk about the responsibility of environmental protection of coal enterprises mainly in enterprise and government two levels. First, enterprises should take the initiative to bear the responsibility of environmental protection. Second, the government should give full play to their supervision and oversight role. But for the long term, both two aspects seem powerless, by the propelling of profits, most companies avail themselves of loopholes, and the government loosen their supervision in order to further improve local finance and tax, therefore, at this stage the responsibility of the environmental protection of coal enterprises have yet to be further improved.

Content of coal enterprises' CER. Coal enterprises must bear the responsibility for environmental protection in their production activities, which can be specifically expressed as: "in the realization of certain economic interests, enterprises should not only protect and save coal resources, but also through a reasonable resource development process, without destroying or breaking the ecological balance of the area."

Enhance awareness of resource saving. As a coal resource explorer, miner, transporter, enterprise must fulfill the saving responsibility of the resources. As coal resources are non-renewable scarce resources, once the use of depletion, we will probably face the crisis of resources exhausted. At the same time, coal resources have gone deep into our daily lives, its utilization rate is much higher than oil, natural gas, solar energy, wind energy and others, this pattern will not change much in the short term. Therefore, taking the non-renewable characteristics and the prevalence of consumption into account, the coal enterprises should take the lead in resource-saving from the "source", strictly obey the relevant operating regulations and laws, and improve the efficiency of resource usage.

Attach importance to environment protection. Coal enterprises take the charge of the development and utilization of coal resources and a series of activities, if they do not timely and effectively repair and restore the mining area surface, underground vegetation, will lead to serious soil erosion, ground collapse and other risks. Meanwhile, the waste gas, sewage produced by production process will cause pollution. So the coal enterprises engaged in related activities, should firstly establish the concept of environmental protection, and correspond it with action. Second, learn advanced mining technology, use advanced mining equipment. Third, dare to innovate, strengthen the corporate culture of environmental protection.

Set up proper management philosophy. Management philosophy is in the scope of business ideas or ideology. Mining industry is quite special; its activities have obvious publicity and advertising effects. Attaching great importance to the cultivation of business philosophy, such as engaging in 
public welfare, environmental protection, can help enterprises to create a better image, and enable them to get the recognized by the whole society. At the same time, through the leading and demonstrate effect, enterprise can also lead other industries to join in protecting environment, ultimately contribute to the harmonious development of society and economy.

\section{Development of Mongolia Coal Industry}

Distribution of coal resources. Mongolia has very rich coal resources, according to a report by the Minister of Mongolia Mineral Resources at the "Coal Mongolia" International Forum in 2013. Mongolia's per capita coal resources are among the first in the world and the total reserves are among the world's top ten, widely distributed, known as "Saudi Arabia in the coal industry". Statistics released by the National Bureau of Statistics in 2014 showed the current total reserves of coal resources in Mongolia is about 162.3 billion tons (including inferred reserves), various types of coal deposits are about 300 seats and proven reserves of coal resources is about 500-1520 million tons. The current amount of coal extraction in Mongolia is mainly from Tavantolgoi, Alag-tolgoi, Baganuur, Sharyn-Gol, Shivee-Ovoo and Nariin-Suhait, accounting for about $90 \%$ of national output. As Figure 1 shows, Mongolia distribution diagram of coal resources, the distribution of coal resources in Mongolia has obvious characteristics, South Gobi region's coal reserves of about 53 billion tons, the region's main coal mine is Tavantolgoi, which is the world's largest coking coal mining and famous for producing coke. Due to the distance from the Chinese border trade port linear distance is about 250 kilometers and relatively convenient transportation, the coal mine from Tavantolgoi can be exported directly to China through rail transport. In the eastern part of Mongolia, lignite is the main resource. The production areas of bituminous coal are also relatively concentrated, mainly in the central and western regions. More than $90 \%$ of the proven reserves of coal are distributed in the central region.

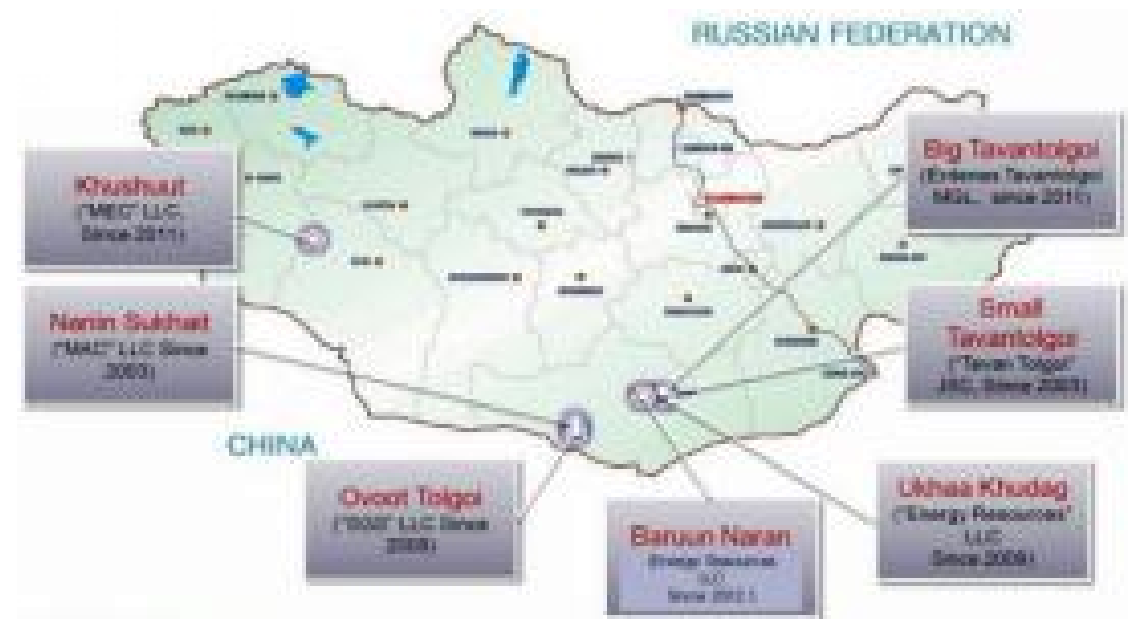

Fig. 1 Main Coal Projects in Southern Mongolia

Types and usage of coal resources. Mongolia has different kinds of coal resource, according to the data released by the National Bureau of Statistics in 2013, the distribution of coal quality in each region of Mongolia is affected by the geological conditions. Its formation and the distribution of the coal qualities are relatively regular. The overall distribution shows the western area of coking coal, steam coal, the southern region of coking coal, in the central area of coking coal and steam coal and the eastern region of lignite. Influenced by the dynamic metamorphism of the Altai fold belt, in the same era of coal series, the overall distribution shows the metamorphic degree gradually increased from east to west. Taking the south-central part of Mongolia as an example, the distribution of coal 
resources has shown in the following Table 1:

Table 1 Coal Quality in Central and Southern Areas of Mongolia

\begin{tabular}{|c|c|c|c|c|c|c|}
\hline \multirow{2}{*}{$\begin{array}{l}\text { Coal-bearing } \\
\text { section }\end{array}$} & \multirow{2}{*}{$\begin{array}{l}\text { Coal } \\
\text { group }\end{array}$} & \multicolumn{3}{|l|}{ Raw coal } & \multirow{2}{*}{$\begin{array}{l}\text { Calorific } \\
\text { value } \\
\text { Kcal/kg }\end{array}$} & \multirow{2}{*}{ Coal type } \\
\hline & & Moisture \% & Ash\% & $\begin{array}{l}\text { Sulfur } \\
\text { content } \%\end{array}$ & & \\
\hline \multirow{3}{*}{ Above } & Above & $1.2-1.6$ & $7.2-23$ & $0.4-0.6$ & 5900 & $\begin{array}{l}\text { 1/3Coking } \\
\text { coal }\end{array}$ \\
\hline & Middle & $1.1-1.6$ & $9-22$ & $0.8-1.6$ & 5900 & $\begin{array}{l}\text { 1/3Coking } \\
\text { coal }\end{array}$ \\
\hline & Lower & $0.7-1.3$ & $9-30$ & $0.7-1.2$ & 5525 & $\begin{array}{l}\text { Coking } \\
\text { coal }\end{array}$ \\
\hline \multirow{4}{*}{ Lower } & \multirow{3}{*}{ Above } & 0.9 & 12.5 & 0.6 & 6800 & $\begin{array}{l}\text { Coking } \\
\text { coal }\end{array}$ \\
\hline & & 0.9 & $11-17$ & 0.5 & 6700 & $\begin{array}{l}\text { Coking } \\
\text { coal }\end{array}$ \\
\hline & & $0.7-1.3$ & $10-19$ & 0.8 & 6520 & $\begin{array}{l}\text { Coking } \\
\text { coal }\end{array}$ \\
\hline & Lower & 0.9 & $9-20$ & 0.65 & 6370 & $\begin{array}{l}\text { Coking } \\
\text { coal }\end{array}$ \\
\hline
\end{tabular}

The export trade of coal resources. At present, coal mining industry has become a pillar industry and an important engine to promote economic growth in Mongolia. Restrained by the backward infrastructure, inadequate processing equipment, low level of mining technology and other conditions, the exploitation of coal resources in Mongolia was between 500-600 million tons in a very long period of time. It was not until 2000 that the national coal production started to grow rapidly. Coal mining in 2004 reached 6.8 million tons, by 2010 the national coal mining has turned 7 times, and reached more than 20 million tons. Mongolia's foreign trade amounted to 11.4 billion US dollars in 2011, only the export value of coal reached 2.26 billion US dollars, accounting for $20 \%$ of total foreign trade, exports accounted for $47 \%$. Mongolia mining 31.1 million tons of coal in 2012, exports 2010 tons, the value of 1.88 billion US dollars. Mongolia's coal export plan is: 50 million tons in 2015, 65 million tons in 2020, 75 million tons in 2025. If the Chinese and Mongolian governments agreed on the Mongolian to the Tianjin Port 1,400 km transport plan, Mongolia can export 30 million tons of coal to Japanese and South Korean market each year. At the same time, Mongolia is also preparing to build a number of coal processing plants to ensure that the international price of coal exports. In China, for example, Mongolia is rich in coal resources, while China has the appropriate capital, technology and market, and during the China's modernization and urbanization process, energy demand has a larger room for growth, including coal. In 2011 Mongolia exported 21 million tons of coal to China, accounting for $99.4 \%$ of its coal exports, export value of 22.7 billion US dollars, accounting for $11.3 \%$ of China's coal imports (as Table 2 shows).

For the cooperation between China and Mongolia, the coal development cooperation and coal trade have become the areas that can best reflect the complementary advantages of the two sides; it also becomes the growth point of the most realistic feasibility and development potential, and an opportunity to achieve rapid development of the coal industry in Mongolia. 
Table 2 Sino-Mongolian Coal Trade

\begin{tabular}{lcccc}
\hline & 2011 & 2012 & 2013 & 2014 \\
\hline $\begin{array}{l}\text { Coal transaction } \\
\text { volume } \\
\quad(\text { Million tons ) }\end{array}$ & 21.1 & 20.5 & 18.2 & 19.0 \\
$\begin{array}{c}\text { Transaction amount } \\
\text { (Billion dollars) }\end{array}$ & 22.7 & 19 & 11.2 & 8.5 \\
\hline
\end{tabular}

\section{Problems in the Development of Coal Enterprises in Mongolia}

Serious resource waste in coal enterprises. From the late 80 s of last century, in order to rapidly enhance the national economic development needs, Mongolia's coal industry began to develop rapidly under the guidance of the international resource needs and domestic policies. There are 26 large and small coal enterprises, respectively, 4 thermal coal production enterprises, 19 civil coal production enterprises and 3 exports of coal production enterprises by 2010 . With the international coal situation improved, the data gradually increased. Restrained by enterprise management mode, mining technology, road transport conditions, the majority of domestic coal mining equipment, technology, low personal quality and some other problems, the waste of coal resources is very serious, at the same time, coal resources can be less effectively exploited, even after the latter part of the washing process, the effective utilization of coal is only maintained at about $30 \%$ level. Effected by the above-mentioned, the exploitation and the use of coal resources waste phenomenon in Mongolia are serious and energy utilization efficiency is low, which is not conducive to the sustainable development of the coal industry.

Serious environmental pollution brought by the coal enterprises. The environmental problems have become one of the biggest problems in the world, the increasing environmental pollution (such as water pollution, air pollution, soil pollution, noise pollution, etc.), has begun to seriously affect the Earth's environment. Compared to other resources, coal mining has a large volume and large occupied areas, in particular, heavy machinery and equipment are used in current large-scale mining of coal resources, and the whole mining process will have a greater negative impact on natural environment, which cannot be easily repaired in short term (as Table 3 shows).

Table 3 Impacts and Hazards of Coal Resources Exploitation

\begin{tabular}{ll}
$\begin{array}{l}\text { Coal-mining } \\
\text { process }\end{array}$ & Impacts and Hazards \\
\hline & $\begin{array}{l}\text { Surface subsidence, emissions of various emissions (methane, etc.), } \\
\text { Mining }\end{array}$ \\
& $\begin{array}{l}\text { resulting in a variety of sewage (water containing heavy metals), } \\
\text { resulting in a variety of mineral dust }\end{array}$
\end{tabular}

Beneficiation All kinds of solid waste, water pollution, air pollution

Mineral Dust pollution, road damage, traffic accidents

transportation

Combustion

Dust pollution, waste pollution, acid rain, greenhouse effect 
At present, Mongolia's economic development depends mainly on coal resources. According to data released by the National Bureau of Statistics in 2014, about $30 \%$ of the national territory has been authorized to carry out a variety of mineral resources exploration and mining. But with the continuous exploiting of coal resources, the destruction and pollution of water resources, forest resources has become increasingly serious, of which only $17 \%$ of domestic water resources can be directly consumed, and nearly $83 \%$ of the water resources has been polluted to varying degrees of pollution. The area of woodlands destroyed by mineral resource development in the country has reached 1360 hectares in 2011, and this figure has been increasing.

Coal enterprises seriously damage the ecosystem. Due to drainage problems in the mining process, the existence of a large number of coal enterprises led to coal underground water level declines, part of the groundwater level dropped to several hundred meters, which caused bad effect on the locals' production and living. According to the first forum for countries to combat desertification held in Ulan Bator in 2009, from 2004 to 2009, Mongolia's water consumption for mining gold ore respectively reached 76.8 million $\mathrm{m} 3,96.8$ million $\mathrm{m} 3$ and 93.8 million $\mathrm{m} 3$. In addition, coal mining is likely to cause large-scale surface stripping and surface subsidence. According to related statistics, the surface subsidence caused by mining area has reached $2.7 \times 104$ $\mathrm{hm} 2$. The daily lives of the locals affected by the destruction of housing, farmland, road caused by the surface subsidence seriously. At the same time, surface subsidence also caused a series of problems, such as withering of lake, withered vegetation and serious damage to the local ecological environment system. According to the Mongolian Ministry of Natural Environment's sampling survey in various mining area showed that the mining area of vegetation ecological recovery rate is also lower, $34.3 \%$ in 2005, 44.1\% in 2006 and 53\% in 2007. Problems caused by the exploitation of coal resources have seriously affected all aspects of life and the environment.

\section{Countermeasures and Suggestions for Improving Environmental Responsibility of Coal Enterprises}

Scientific economic approach coordinating with legal constraints. The development of enterprise economy should adopt a scientific and reasonable way, coordinating with legal constraints at the same time, to implement it to the daily operation and management of enterprises. For the coal industry in Mongolia is currently facing the conflict between the rapid economic upgrading and environmental protection, first of all, from the national and enterprise levels to invest a lot of money and formulate a scientific and reasonable strategy, so that each industry has a clear division of responsibilities to realize the institutionalization of production activities of coal enterprises. Secondly, focus on improving the business skills of employees. Through the establishment of effective staff training mechanisms and incentives and improving the operational skills of front-line operators to achieve the professional and scientific management from the mining process to the use of coal resources, to reduce the middle of the various sectors of the waste of coal resources. Thirdly, the current coal industry in Mongolia in the exploration and mining and personnel, equipment and other aspects of the foundation is relatively weak, some mining companies mining methods still lags behind. Therefore, the state and the coal enterprises should take the long-term plan, to vigorously introduce advanced technology, equipment and professional and technical personnel. Through popularizing new technologies, equipment, high-quality personnel in the coal industry can improve the efficiency of the industry, so as to realize the sustainable development of the coal industry in Mongolia.

Combine exploitation, protection and management. Social and economic development is closely 
related to environmental protection, environmental protection is a key factor in promoting economic development. At present, during the process of mining of coal resources, Mongolian coal enterprises should strengthen the scientific and correct awareness of environmental protection training. The coal enterprises should take the development of relevant work plans and the corresponding protective measures, combine mining and protection, mining and governance to reduce the damage to the minimum during resources exploitation processing, so as to achieve effective protection of the ecological environment. For areas that have been formed with various kinds of pollution and ecological damage, Mongolian coal enterprises should stop the pollution discharge and various processes of destruction of ecosystems. Through all kinds of countermeasures (such as establishing sewage treatment plant for polluted water, recycling the use of emissions, the implementation of regional central heating, changing the fuel composition and removing of the majority of sulfur in coal, thereby reducing the pollution of the atmosphere, and continuously improve the utilization of coal gangue and slime, coal mine gas drainage utilization and mine water utilization), we try to repair and restore the region's original landscape and ecosystems.

Develop the circular economy vigorously. Enterprises should resort to a variety of media and channels, such as vigorously developing the enterprise's environmental protection culture, enhancing the environmental awareness and participation of employees, thus in the process of the production and use, they can consciously to protect the environment. According to relevant articles of association, establishing certain reward and punishment systems can really make workers take actions to protect the environment. Enterprises should develop recycling economy and establish resource conservation responsibility system, put the resource conservation into the daily management process, speed up the development of science and technology and develop circular economy technology. As the recycling economy is usually difficult to have significant returns in short term, companies need a firm conviction to keep on developing circular economy.

\section{Conclusions}

At present, the Mongolian economy is in a period of rapid growth. As the country's main support and pillar industry to achieve economic growth, the coal industry has brought new opportunities for the development of coal enterprises. But there are some environmental issues to be resolved when coal enterprises in the face of the pursuit of economic growth-How to realize the coordinated development of social economy and environment protection requires the coal enterprises to seriously and objectively analyze their economic and social development trends and environmental responsibility. They should focus on the model of sustainable development and vigorously develop the circular economy. At the same time, coal enterprises should be environmentally conscious and conservation from beginning to end during their exploration, mining, marketing and other production processes, and focusing on waste recycling in the production process. Coal enterprises should pay attention to the internal energy, fuel and other choices, limited selection of non-polluting, green and other organic fuels; careful analysis of the waste generated and energy consumption situation at end of the industry chain to maximize the realization of the production process harmless, so as to achieve the unity of economic and environmental coordinated development.

\section{References}

[1] Bai Pingze. Review on Corporate Environmental Responsibility. Journal of Shaanxi Normal University VOL. 2 (2006), p.23-126 (In Chinese)

[2] Conference Proceedings: National Forum on Combating Desertification (2009), p. 132. (In 


\section{Chinese)}

[3] Graff Zivin: A Modigliani-Miller Theory of Altruistic Corporate Social Responsibility. Topics in Economic Analysis and Policy. VOL. 5 (2005), p.98-102

[4] Jing Taijia, Peng Mao Dolma. Brief Review on Corporate Environmental Responsibility: Qaidam Development Research. VOL. 2 (2008), p.52-55 (In Chinese)

[5] Mongolian statistical yearbook Bulletin (2005-2013).

[6] Qi Lei: Brief Talk on Sustainable Development of Chinese Coal Enterprise. Zhongzhou Coal. Vol. 117-119 (2012) (In Chinese)

[7] Sarangerel Purevd. Study on the Problems and Countermeasures of Mongolia's Coal Export Trade with China. Beijing Institute of Technology (2005) (In Chinese)

[8] The Energy Investment Research Report of Mongolia. (2015-2020) (In Chinese)

[9] Wu Limin: Brief Review on Corporate Environmental and Social Responsibility. Journal of Wuhan Polytechnic University. VOL. 2 (2001), p.78 (In Chinese)

[10] Wu Jiaojun: Review on Corporate Environmental Responsibility. Shanghai Academy of Social Science Press. VOL.24-36 (2007), p.24 (In Chinese)

[11] Wu Zhen: Analysis on Legitimacy of Corporate Environmental Responsibility Establishment__From the Perspective of Sustainable Development. Contemporary Law Review. Vol. 21 (2007), p. 5 (In Chinese)

[12] Yang Wenrui: Analysis on Coal Enterprise Environmental Responsibility (2014) (In Chinese)

[13]Zhang Xiaoli: Research on Chinese Corporate Environmental Responsibility (2010) (In Chinese)

[14] Information on http://www.nso.mn/

[15]Information on https://mn.wikipedia.org/

[16] Information on http://www.coalmining.mn/

[17] Information on www.china-nengyuan.com/news/71296.htm 